\title{
PENDAMPINGAN PETANI MUDA KOPI ROBUSTA DALAM UPAYA MENINGKATKAN EKSISTENSI PETANI KOPI DI DESA AMADANOM, KECAMATAN DAMPIT, KABUPATEN MALANG
}

\author{
M. Syaprin Zahidii ${ }^{1}$,Havidz Ageng Prakoso ${ }^{2}$, Hutri Agustino ${ }^{3}$, Erfan Dani Septia ${ }^{4}$ \\ ${ }_{1,2,3,4}$ Universitas Muhammadiyah Malang. \\ Email: syaprin123@umm.ac.id
}

\begin{abstract}
Amadanom Village, Dampit District, Malang Regency is known as Robusta coffee granary but at present there are problems faced by coffee farmers in Amadanom Village. The problem is about the regeneration of coffee farmers who are hampered by the lack of interest in the young generation in Amadanom Village to continue their parents' profession as coffee farmers. So, in this service program we focus the program on coffee literacy classes which are held intensively for 30 days. The purpose of this activity is to encourage young people in Amadanom Village to continue their parents' work as coffee farmers. The method of activities that we do is to hold workshops that bring experts in the fields of Branding, Information Technology, Agrotechnology and Online Marketing. This community service has succeeded in forming a Young Farmers Group who is committed to continuing the profession of their parents as coffee farmers in Amadanom Village.
\end{abstract}

Key Words : Amadanom, Literacy Class, Coffee Farmer, Robusta, Regeneration

\begin{abstract}
Abstrak. Desa Amadanom, Kecamatan Dampit, Kabupaten Malang dikenal sebagai lumbung kopi robusta namun pada saat ini ada permasalahan yang dihadapi oleh para petani kopi di Desa Amadanom. Masalah itu adalah tentang regenerasi petani kopi yang terhambat akibat dari kurang berminatnya generasi muda di Desa Amadanom untuk melanjutkan profesi orang tuanya sebagai petani kopi. Maka, dalam program pengabdian ini kami memfokuskan program pada kelas literasi kopi yang diadakan secara intensif selama 30 hari. Tujuan dari kegiatan ini adalah mendorong generasi muda di Desa Amadanom untuk melanjutkan pekerjaan orang tuanya menjadi petani kopi. Adapun metode kegiatan yang kami lakukan adalah dengan mengadakan workshop yang mendatangkan para ahli di bidang Branding, Teknologi Informasi, Agroteknologi dan Marketing Online. Kegiatan pengabdian ini berhasil membentuk Kelompok Petani Muda yang berkomitmen untuk meneruskan Profesi orang tuanya sebagai petani kopi di Desa Amadanom.
\end{abstract}

Kata Kunci : Amadanom, Kelas Literasi, Petani Kopi, Robusta, Regenerasi

\section{PENDAHULUAN}

Coffee Shop sebagai gaya hidup masyarakat perkotaan menjadi tren hampir diseluruh kota besar Indonesia (Katarika \& Syahputra, 2017). Hal tersebut juga terjadi di Kota Malang, setiap hari Coffee Shop tidak sepi dari pengunjung yang banyak didominasi oleh Mahasiswa dan juga pekerja kantoran. Hal ini tidak bisa dilepaskan dari kondisi geografis kota Malang yang cocok untuk tempat berkembangnya Coffee Shop.

Varian Kopi yang menjadi unggulan dan selalu ada hampir di semua Coffee Shop Kota Malang adalah Kopi Robusta yang berasal dari Desa Amadanom, Kecamatan Dampit Kabupaten
Malang. Sebagaimana diungkapkan oleh beberapa pemilik Coffee Shop yang kami temui di Kota Malang yaitu Bapak Ilham dan Bapak Ghozi (Mubarok \& Muhammad, 2019). Hal tersebut akhirnya medorong ketertarikan tim pengabdian kami untuk meninjau lokasi tersebut. Namun, ketika kami meninjau lokasi tersebut kami mendapati fakta yang menarik yaitu terjadi penurunan minat dari generasi muda dengan rentang umur 20-30 tahun untuk melanjutkan profesi orang tuanya menjadi petani kopi Robusta. Hal tersebut terjadi karena mereka berpendapat bahwa bekerja di Kota lebih menjamin masa depan mereka dibandingkan hanya menjadi petani Kopi. 
Hal tersebut menurut kami akan menjadi masalah di masa depan karena akan terjadi lost generation petani kopi di Desa Amadanom, Kecamatan Dampit, Kabupaten Malang. Sebagaimana diutarakan oleh salah satu petani kopi yang sudah sepuh di Desa Amadanom yaitu bapak Suliyadi yang mengatakan bahwa akan terjadi masalah di masa depan bagi regenerasi petani kopi Robusta yang menjadi ciri khas Desa Amadanom karena anak-anak muda di Desa Amadanom lebih suka bekerja di kota daripada menjadi petani kopi (Suliyadi, 2019). Hal yang sama juga diungkapkan oleh Kepala Desa
Amadanom yaitu Bapak Sarimin yang menyebutkan bahwa masalah terbesar dari Desa Amadanom dalam mengembangkan Kopi Robusta adalah kurangnya minat generasi muda di Amadanom untuk mengikuti jejak orang tuanya menjadi petani kopi (Sarimin, 2019).

Pernyataan dari kepala Desa Amadanom tersebut kemudian kami sinkronkan dengan data dari Badan Pusat Statistik Kabupaten Malang tahun 2018 yang kemudian kami gambarkan dalam bentuk grafik sebagaiman terdapat pada gambar di bawah ini:

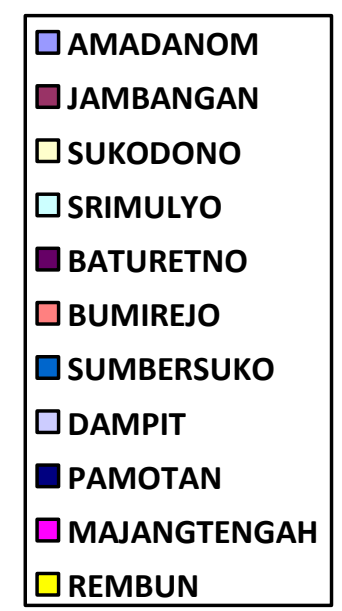

Sumber: BPS KABUPATEN MALANG, 2018

Berdasarkan data grafik tersebut dapat dideskripsikan bahwa Jumlah keseluruhan penduduk di Kecamatan Dampit adalah 136.324 jiwa. Dari jumlah tersebut $9 \%$ nya adalah penduduk Desa Amadanom yang jika dikonversi menjadi 6.877 jiwa. Dari 6.877 jiwa tersebut sejumlah 105 jiwa penduduk usia produktif memilih untuk keluar dari Desa Amadanom dan tidak melanjutkan usaha orang tuanya menjadi petani kopi.

Berdasarkan data tersebut diatas dan mengamati permasalahan yang ada di Desa Amadanom maka kami memutuskan untuk membuat kegiatan pengabdian yang fokus utamanya adalah kaderisasi petani muda kopi robusta. Pemilihan Petani muda kopi robusta karena harapan kami di masa depan mereka dapat melanjutkan profesi orang tuanya menjadi petani kopi robusta.

Dalam rangka memudahkan kami pada proses pelaksanaan pengabdian maka kami bekerjasama dengan Pihak desa dan kelompok petani kopi yang ada di Desa Amadanom untuk menjaring peserta yang akan dilibatkan dalam kegiatan pendampingan petani muda kopi Robusta di Desa Amadanom. Dari hasil penjaringan tersebut didapatkanlah calon-calon peserta yang berkomitmen untuk ikut dalam kegiatan pendampingan ini.

\section{METODE PELAKSANAAN}

Metode yang digunakan dalam proses pendampingan petani muda kopi Robusta ini adalah dengan metode workshop yang dirancang dalam bentuk kelas literasi kopi dibawah supervisi dari Kepala Dinas Pemberdayaan Masyarakat dan Desa Kabupaten Malang, Drs. Suwadji., S.IP. M.Si.

Kelas literasi kopi ini akan terbagi dalam 6 sesi tematik yang diikuti oleh para peserta sebagaimana terdaftar dalam tabel sebelumnya. Beberapa tema penting yang akan dibahas dalam kelas literasi kopi ini yaitu membangun 
mentalitas petani kopi dari kaum millenial, membangun branding dari produk kopi robusta, metode penjualan online kopi robusta sampai dengan diversifikasi produk kopi seperti pengolahan kulit biji kopi menjadi pupuk cair dan lain-lain. Pada akhir kelas akan diadakan festival kopi yang akan kami agendakan menjadi festival tahunan di Desa Amadanom sehingga diharapkan dapat juga mendatangkan keuntungan bagi para petani kopi di Desa Amadanom.

Adapun penjabaran mengenai metode serta tahapan dalam kegiatan pengabdian ini kami lampirkan dalam bentuk tabel pada Tabel2.

Tabel 1. Peserta Pendampingan Petani Muda Kopi Robusta di Desa Amadanom

\begin{tabular}{|c|c|c|}
\hline No & Nama & Jenis Kelamin \\
\hline $\mathbf{1}$ & Agung Prasojo & Laki-laki \\
\hline $\mathbf{2}$ & Sri Wahyuni & Perempuan \\
\hline $\mathbf{3}$ & Angga Fredi & Laki-laki \\
\hline $\mathbf{4}$ & Arip M & Laki-Laki \\
\hline $\mathbf{5}$ & Dimas Budi Kusuma & Laki-laki \\
\hline $\mathbf{6}$ & Erham & Laki-Laki \\
\hline $\mathbf{7}$ & Erwin Candra & Laki-laki \\
\hline $\mathbf{8}$ & Faisal Efendi & Laki-Laki \\
\hline $\mathbf{9}$ & Fian & Laki-Laki \\
\hline $\mathbf{1 0}$ & Hasyim & Laki-Laki \\
\hline $\mathbf{1 1}$ & Hendrak & Laki-Laki \\
\hline $\mathbf{1 2}$ & Kaji Ibrahim & Laki-Laki \\
\hline $\mathbf{1 3}$ & Memet & Perempuan \\
\hline $\mathbf{1 4}$ & Mey Sri Lestari & Perempuan \\
\hline $\mathbf{1 5}$ & Nita Dewi & Perempuan \\
\hline $\mathbf{1 6}$ & Novi & Laki-Laki \\
\hline $\mathbf{1 7}$ & Nurdianto & Laki-Laki \\
\hline $\mathbf{1 8}$ & Rohmat & Laki-Laki \\
\hline $\mathbf{1 9}$ & Yandik Kurniawan & Laki-Laki \\
\hline $\mathbf{2 0}$ & Tyo & Perempuan \\
\hline $\mathbf{2 1}$ & Yashinta & \\
\hline
\end{tabular}

Sumber: Penulis (2019)

Tabel 2. Tahapan Kegiatan Pengabdian dan Metode Pelaksanaan

\begin{tabular}{|c|c|l|}
\hline No & Tanggal & \multicolumn{1}{c|}{ Kegiatan } \\
\hline 1 & 19 April 2018 & $\begin{array}{l}\text { Koordinasi dan observasi lapang dilakukan oleh tim pengabdian PPDM dengan } \\
\text { perangkat desa di Amadanom. Dalam observasi lapang tersebut didapatkan } \\
\text { informasi tentang kondisi geografis dari desa amadanom yaitu luas wilayah } 6,11 \\
\text { Km2. Jumlah berpenduduk sebanyak 6.912 orang. Topografi desa berbukit dan } \\
\text { kebun kopi menjadi salah satu potensi yang dimiliki oleh Desa sebagaimana } \\
\text { diungkapkan oleh kepala desa Amadanom Bapak Sarimin. Sayangnya itu belum } \\
\text { muncul secara eksplisit di blueprint dea }\end{array}$ \\
\hline 2 & 22 April 2018 & $\begin{array}{l}\text { Pendampingan penyusunan blueprint desa. bertempat di kantor desa Amadanom. } \\
\text { Setelah itu tim pengabdian melakukan observasi lanjutan untuk memetakan potensi } \\
\text { kopi yang dimiliki oleh desa amadanom. Pada observasi lanjutan ini tim } \\
\text { pengabdian juga mulai mampu memetakan masalah yang ada di desa amadanom. } \\
\text { Permasalahan utama yang mereka miliki adalah terkait dengan regenerasi petani } \\
\text { kopinya dimana usia-usia produktif/generasi muda di Amadanom banyak yang } \\
\text { meninggalkan desa untuk bekerja di luar amadanom dan tidak banyak yang } \\
\text { meneruskan profesi orang tuanya sebagai petani kopi. info ini didapatkan dari } \\
\text { kelompok-kelompok tani yang ada di Amadanomi }\end{array}$ \\
\hline
\end{tabular}




\begin{tabular}{|c|c|c|}
\hline No & Tanggal & Kegiatan \\
\hline 3 & 17 Juni 2019 & $\begin{array}{l}\text { Berdasarkan hasil observasi pada tanggal } 22 \text { April 2018. maka, program utama } \\
\text { yang disusun oleh tim pengabdian untuk tahun pertama adalah diadakannya kelas } \\
\text { literasi kopi. Kelas literasi kopi dijadikan program unggulan untuk memberikan } \\
\text { mindset baru pada masyarakat Amadanom tentang keunggulan dari kopi yang } \\
\text { mereka miliki. Terkait dengan hal itu, peserta yang dipilih untuk menjadi peserta } \\
\text { pada kelas literasi kopi adalah pemuda-pemudi dengan rentang umur 19-25 tahun. } \\
\text { Disinilah tantangan bagi tim pengabdian untuk merekrut peserta sehingga tim desa } \\
\text { yang diwakili oleh carik desa amadanom bapak pitono turun langsung untuk } \\
\text { menjaring para peserta. }\end{array}$ \\
\hline 4 & 29 Juli 2019 & $\begin{array}{l}\text { Peresmian kelas literasi kopi dilaksanakan di Balai desa Adanom. Peresmian kelas } \\
\text { literasi kopi ini yang dibuka langsung oleh Kepala Dinas Pemberdayaan } \\
\text { Masyarakat dan Desa Kabupaten Malang, Drs. Suwadji., S.IP. M.Si. Kelas literasi } \\
\text { kopi tersebut terbagi dalam delapan sesi tematik dengan melibatkan } 25 \text { kader } \\
\text { petani kopi usia produktif yang tersebar dari beberapa dusun di wilayah Desa } \\
\text { Amadanom. }\end{array}$ \\
\hline 5 & 30 Juli 2019 & $\begin{array}{l}\text { Tim Pengabdian melakukan pertemuan dengan para peserta kelas literasi kopi yang } \\
\text { sudah terdaftar untuk membagikan seragam dan peralatan kelas yang nantinya } \\
\text { digunakan pada kelas literasi kopi. }\end{array}$ \\
\hline 6 & 2 Agustus 2019 & $\begin{array}{l}\text { Sesi Pertama Dalam kelas literasi kopi diisi oleh Bapak Jamrozi. Dalam materi ini } \\
\text { Bapak Jamrozi yang telah sukses dalam membranding kampoug warni-warni } \\
\text { jodipan di Kota Malang kami libatkan dalam kegiatan pengabdian ini. Tujuan kami } \\
\text { melibatkan Bapak Jamrozi agar para peserta kelas literasi kopi memahami } \\
\text { pentingnya branding produk kopi mereka. }\end{array}$ \\
\hline 7 & 9 Agustus 2019 & $\begin{array}{l}\text { Materi berikutnya Dalam kelas literasi kopi diberikan oleh saudara gigih seorang } \\
\text { peternak lebah madu. Dalam sesi ini kami mengharapkan para peserta dapat } \\
\text { melakukan product development yang akhirnya akan menjadi ciri khas para petani } \\
\text { kopi di Desa Amadanom. Harapan kami para petani kopi itu mampu menghasilkan } \\
\text { kopi dengan cita rasa madu. }\end{array}$ \\
\hline 8 & 12 Agustus 2019 & $\begin{array}{l}\text { Materi pada sesi ini diberikan oleh Bapak Fuad Nasvian yang menjelaskan tentang } \\
\text { pentingnya desain produk kemasan kopi Karena dengan desain yang menarik } \\
\text { customer akan lebih tertarik untuk membeli produk kopi di Amadanom. Hal ini } \\
\text { menjadi penting bagi peserta kelas literasi kopi yang notabene belum mengemas } \\
\text { produk kopinya dengan baik sehingga tidak menarik jika ditampilkan. }\end{array}$ \\
\hline 11 & 13 Agustus 2019 & $\begin{array}{l}\text { Materi pada sesi ini diberikan oleh ibu yuyun ariani seorang online marketer } \\
\text { dengan brand iyab. dalam materinya ibu yuyun arinai menjelaskan tentang } \\
\text { pentingnya para petani kopi untuk memahami perkembangan penjualan kopi } \\
\text { secara online yang sangat marak setelah menjamurnya market place seperti } \\
\text { Bukalapak, Lazada, Shoppe dan lain-lain. Kemudian, Ibu Yuyun mennyarankan } \\
\text { agar para petani kopi membuat akun di market place untuk belajar jualan online. }\end{array}$ \\
\hline 12 & 14 Agustus 2019 & $\begin{array}{l}\text { Sesuai dengan agenda yang telah disusun oleh tim pengabdian maka pada tangal } \\
14 \text { agustus } 2019 \text { diadakanlah festival kopi untuk pertama kalinya di desa } \\
\text { amadanom sekaligus memberikan hibah untuk perangkat desa amadanom dalam } \\
\text { bentuk mesin roasting kopi serta memberikan sertikat kepada peserta kelas literasi } \\
\text { kopi. Dalam festival ini Kepala Dinas Pemberdayaan Masyarakat dan Desa } \\
\text { Kabupaten Malang, Drs. Suwadji., S.IP. M.Si menandatangani prasasti kopi } \\
\text { sebagai simbol bangkitnya industri kopi di desa Amadanom.. }\end{array}$ \\
\hline
\end{tabular}

Sumber: Penulis (2019) 


\section{HASIL DAN PEMBAHASAN}

Kelas literasi kopi yang menjadi program utama dalam pengabdian masyarakat ini diawali dengan peresmian kelas yang dilakukan oleh Kepala Dinas Pemberdayaan Masyarakat dan Desa Kabupaten Malang, Drs. Suwadji., S.IP. M.Si pada tanggal 29 Juli tahun 2019 dengan peserta 21 petani kopi robusta yang ada di Desa Amadanom. Berikut dokumentasi dari kegiatan peresmian kelas tersebut.

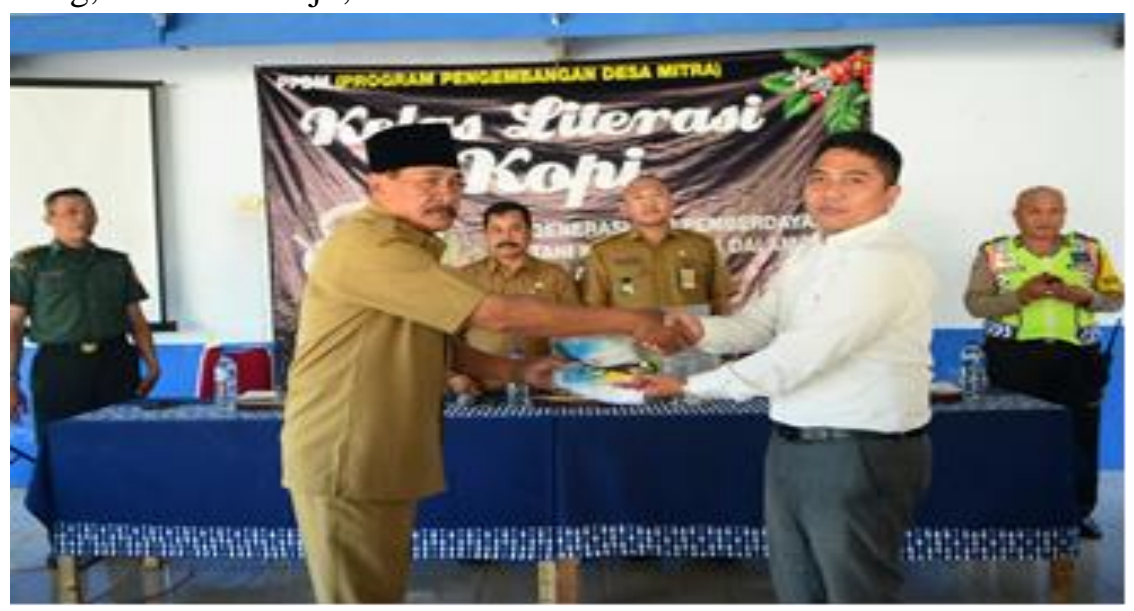

Gambar 1. (Dalam gambar ketua tim pengabdian PPDM UMM, M. Syaprin Zahidi, M.A. menyerahkan secara simbolik peralatan kelas literasi kopi kepada Kepala Desa Amadanom Bapak Sarimin. Disaksikan oleh Kepala Dinas Pemberdayaan Masyarakat dan Desa Kabupaten Malang, Drs. Suwadji., S.IP. M.Si dan camat Dampit.

Pasca peresmian kelas literasi kopi sepakati bahwa kelas akan dimulai dari tanggal 2 tersebut, pada tanggal 30 Juli 2019 kami Agustus 2019 sampai dengan tanggal 13 Agustus mengadakan pertemuan dengan para peserta 2019. Berikut adalah merupakan dokumentasi untuk menjelaskan mengenai schedule kelas. pertemuan kami dengan para peserta kelas Dalam pertemuan tersebut akhirnya kami literasi kopi di Desa Amadanom

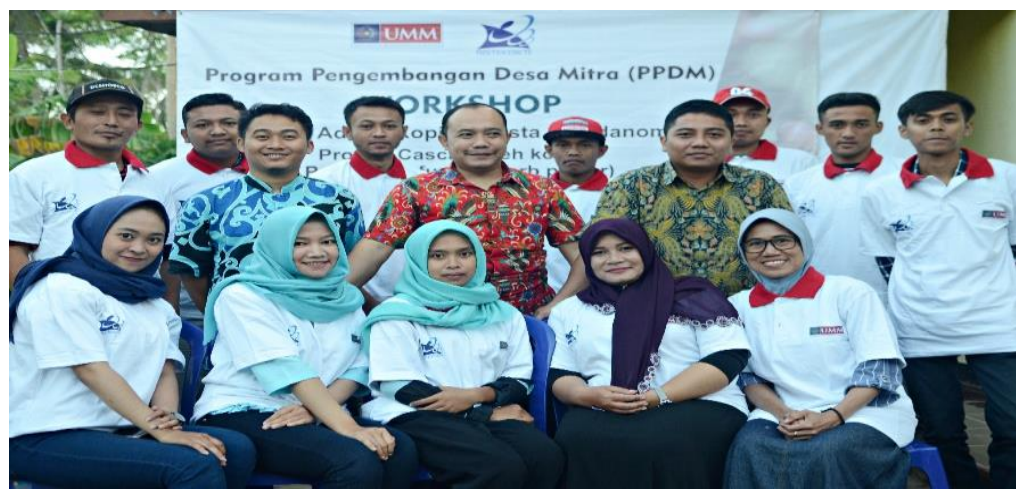

Gambar 2. Tim pengabdian berfoto bersama para peserta kelas literasi kopi pasca briefing untuk persiapan kelas tanggal 2 Agustus 2019

Setelah pertemuan dengan para peserta kelas literasi kopi kami lakukan. Maka pada tanggal 2 Agustus 2019 kelas literasi kopi dimulai dengan materi tentang Destination Branding yang disampaikan oleh bapak Jamrozi Dosen Ilmu Komunikasi Universitas Muhammadiyah Malang yang memiliki pengalaman dalam melakukan branding terhadap potensi wisata di suatu daerah seperti di
Banyuwangi ataupun di Kota Malang yang terkenal dengan kampung warna-warni Jodipan.

Harapan kami dengan adanya materi branding yang diberikan oleh Bapak Jamrozi ini maka akan menimbulkan kesadaran di tengah para petani kopi Robusta desa Amadanom tentang potensi desa yang bisa mereka kembangkan dan ini menjadi target utama dari materi pertama ini. Rata-rata ketika kami amati 
para peserta mulai sadar dengan potensi-potensi desa mereka yang intinya adalah kopi namun bisa dikemas dengan varian-varian lainnya seperti wisata edukasi petik kopi atau hal-hal lainnya yang bisa dikembangkan sebagai penunjang kopi.

Hasil dari kelas destination branding memunculkan ide dikalangan peserta untuk membranding desa amadanom sebagai tujuan dari desa wisata kopi sehingga para peserta yang tentunya juga kami fasilitasi menyepakati untuk menjadikan bukit di desa Amadanom sebagai destinasi wisata kopi yang diberi nama bukit van d' kock.

Pasca materi tentang destination materi tentang value added kopi robusta amadanom menjadi produk Cascara (Teh Kopi) dan produk Parfum (Absorb Power) dalam kelas ini kami melibatkan mahasiswamahasiswa yang sedang melaksanakan KKN di Desa Amadanom untuk memberikan materi tentang topik ini karena ada beberapa mahasiswa di kelompok KKN tersebut yang juga memiliki pengalaman dalam diversifikasi produk kopi. Harapan kami dengan adanya pembekalan diversifikasi produk kopi maka para petani kopi di Desa Amadanom akhirnya akan memiliki keterampilan baru selain hanya menanam pohon kopi. Berikut adalah dokumentasi dari kelas value added tersebut.

branding, materi kelas kami lanjutkan dengan

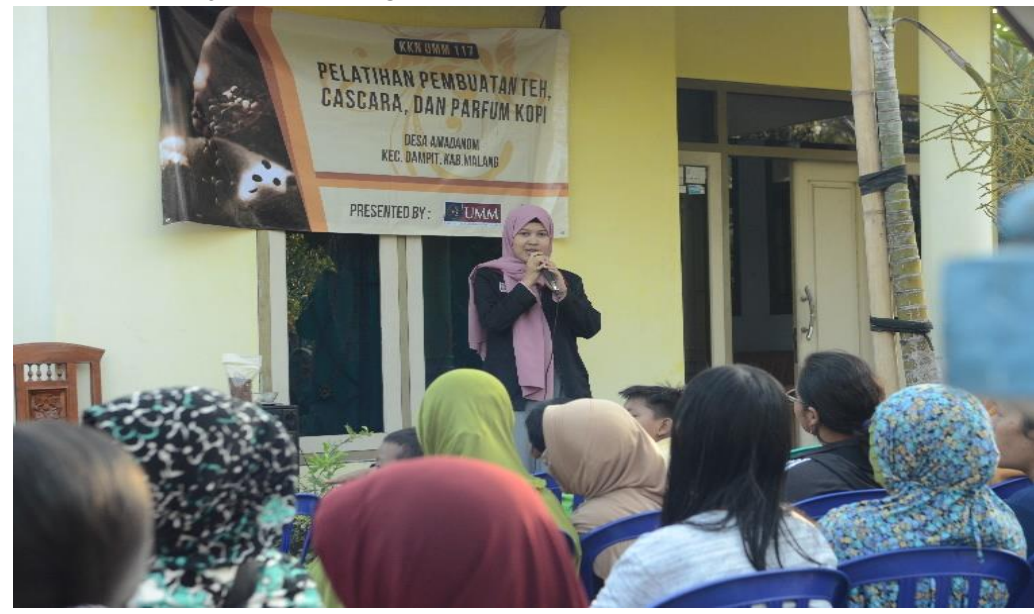

Gambar 3. Tampak dalam gambar pembicara dari peserta KKN di Desa Amadanom dalam workshop value added kopi robusta pada tanggal 3 Agustus 2019

Pasca kegiatan tersebut para peserta kelas literasi kopi akhirnya menyepakati untuk memproduksi produk cascara dan parfum yang produksinya akan dimulai sebulan setelah kelas adapun hasil dari produknya memang masih harus melalui proses uji kelayakan untuk dijual sehingga membutuhkan proses yang cukup lama.

Materi berikutnya dari kelas literasi kopi adalah tentang ternak lebah madu di wilayah kebun kopi sebagai diversifikasi produk kebun kopi yang dilaksanakan pada tanggal 910 Agustus 2019. Materi ini disampaikan oleh saudara Gigih Syukron seorang peternak lebah madu yang cukup sukses. Harapan kami dengan adanya materi ternak lebah madu ini yang juga bersumber dari kopi akan memberikan pemahaman yang baru bagi para petani kopi tentang diversifikasi produk kopi.
Follow up dari Program ini adalah adanya pendampingan oleh saudara Gigih kepada para petani kopi di desa Amadanom untuk beternak lebah madu di lahan kopi yang mereka miliki. Pada akhirnya perlahan-lahan para petani kopi di desa Amadanom mulai belajar beternak lebah madu. Setelah materi tentang ternak lebah madu dengan perpaduan kopi. Kelas literasi kopi dilanjutkan dengan materi tentang diversifikasi kopi melalui industri marketing 4.0. yang diadakan pada tanggal 12 Agustus 2019. Materi tentang topik ini disampaikan oleh Ibu Yuyun Ariani seorang praktisi marketing online yang sudah cukup lama menjalankan bisnis onlinenya. Dalam materi ini pemateri memberikan pelatihan teknis mengenai penjualan kopi secara online melalui facebook, instagram dan market place seperti Lazada, Shoppee dan lain-lain. Para 
petani kopi juga diberikan bimbingan teknis mengenai pembuatan google business yang pada akhirnya nanti akan sangat bermanfaat bagi perkembangan bisnis kopi mereka. Berikut ini adalah dokumentasi kelas literasi kopi dengan topik digital marketing.

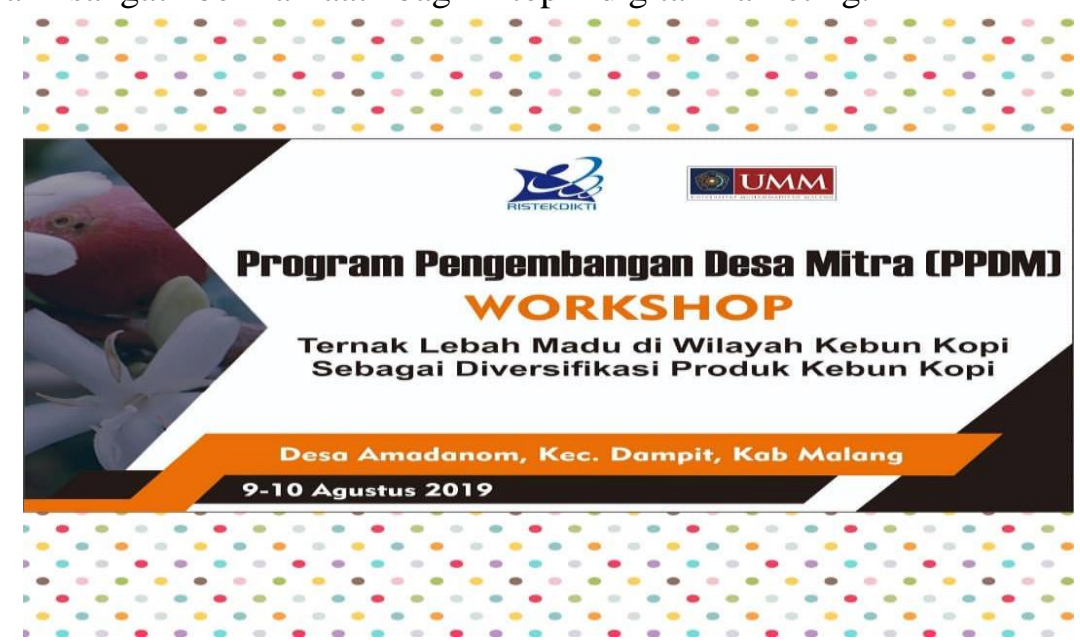

Gambar 4. Banner workshop ternak lebah madu di Desa Amadanom

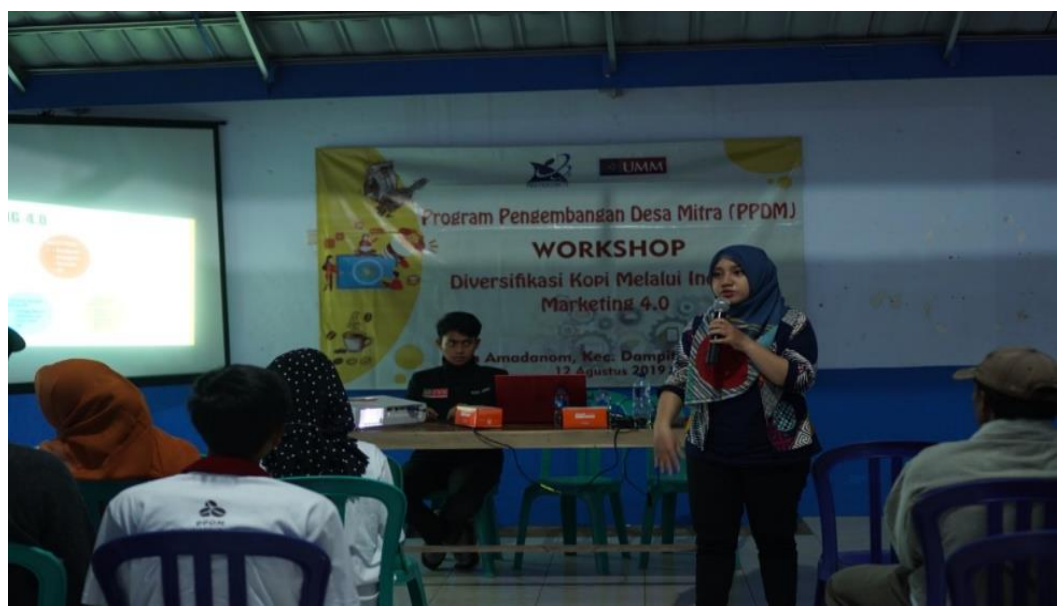

Gambar 5. Tampak dalam gambar ibu Yuyun Ariani (Owner Sysgoodstore) sedang menyampaikan materi dan pelatihan teknis tentang digital marketing kepada para peserta kelas literasi kopi.

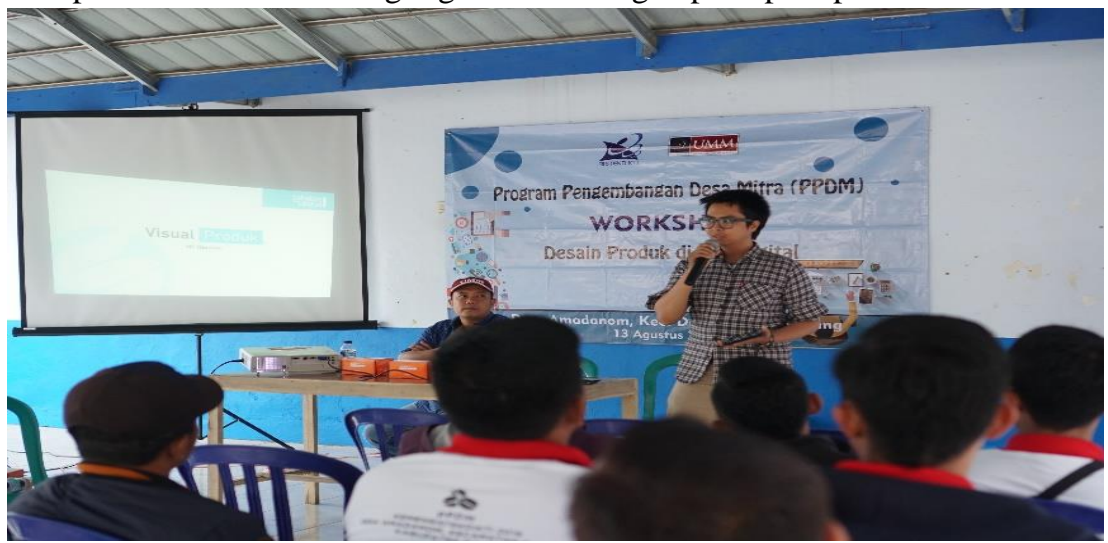

Gambar 6. Tampak dalam gambar Bapak Fuad Nasvian sedang memberikan materi tentang desain produk kemasan kopi.

Pasca materi dari ibu yuyun ariani peserta kelas literasi kopi kemudian mencoba untuk membuat akun google bisnis dan akun di market place walaupun kendalanya di desa
Amadanom adalah jaringan internet yang perlu penambahan bandwitch. Hal inipun sudah kami bicarakan dengan para aparat desa. 
Pertemuan berikutnya dari kelas literasi kopi diadakan pada tanggal 13 Agustus 2019 yang membahas topik tentang desain produk di era digital. Materi tentang topik ini disampaikan oleh Bapak Fuad Nasvian, seorang Praktisi desain produk dan juga Dosen di Prodi Ilmu Komunikasi Universitas Muhammadiyah Malang. Dalam kelas literasi kopi ini Bapak Fuad Nasvian memberikan bimbingan teknis mengenai kemasan produk kopi yang bisa meningkatkan harga jual dari kopi robusta di Amadanom.

Pada topik desain produk ini juga bapak fuad nasvian menunjukkan beberapa contoh kemasan produk kopi yang sudah ada dan cocok digunakan di era digital marketing ini. Berikut adalah dokumentasi kelas yang dimentori oleh. Bapak Fuad Nasvian.
Menindaklanjuti materi dari Bapak Fuad Nasvian itu kami kemudian mendorong para peserta kelas literasi kopi untuk berkonsultasi lebih lanjut tentang desain kemasan bagi produk-produk kopi mereka walaupun kenyataannya masih dalam proses hingga saat ini.

Materi dari Bapak Fuad Nasvian tersebut menjadi materi terakhir dalam kelas literasi kopi pada program pengabdian kami. Setelah kelas literasi kopi maka kami mengadakan festival kopi di Desa Amadanom. Harapan kami dengan adanya festival kopi di Desa Amadanom maka ini akan mejadi festival yang rutin dilakukan minimal setahun sekali dan hal ini telah disetujui oleh kepala Desa Amadanom yaitu Bapak Sarimin. Gambar-gambar berikut ini akan menunjukkan kegiatan-kegiatan yang kami lakukan dalam festival kopi di Desa Amadanom.

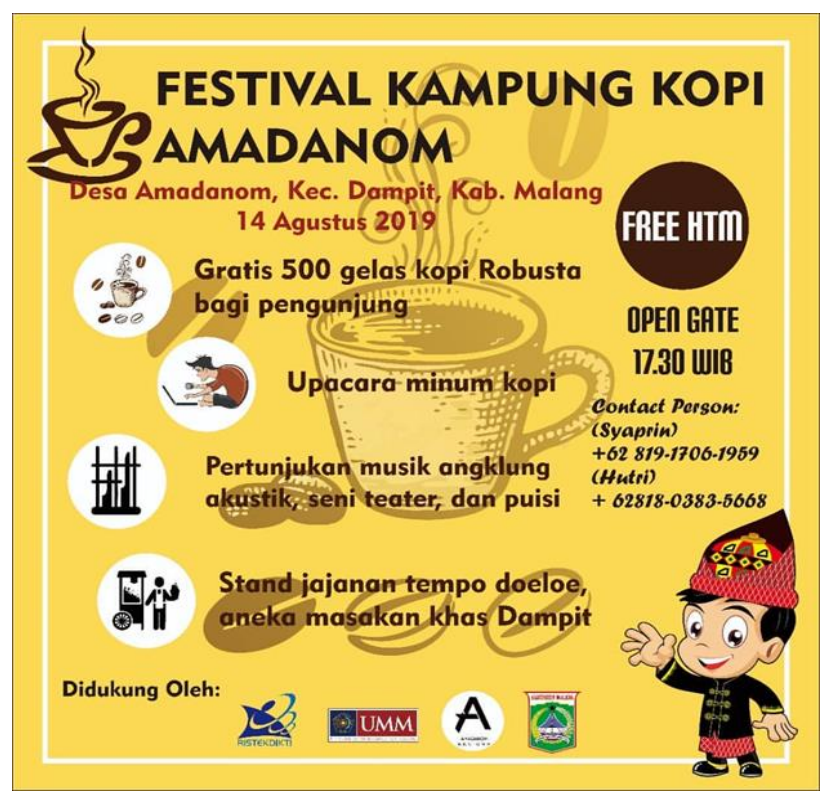

Gambar 7. Poster Acara Festival Kopi Di Desa Amadanom

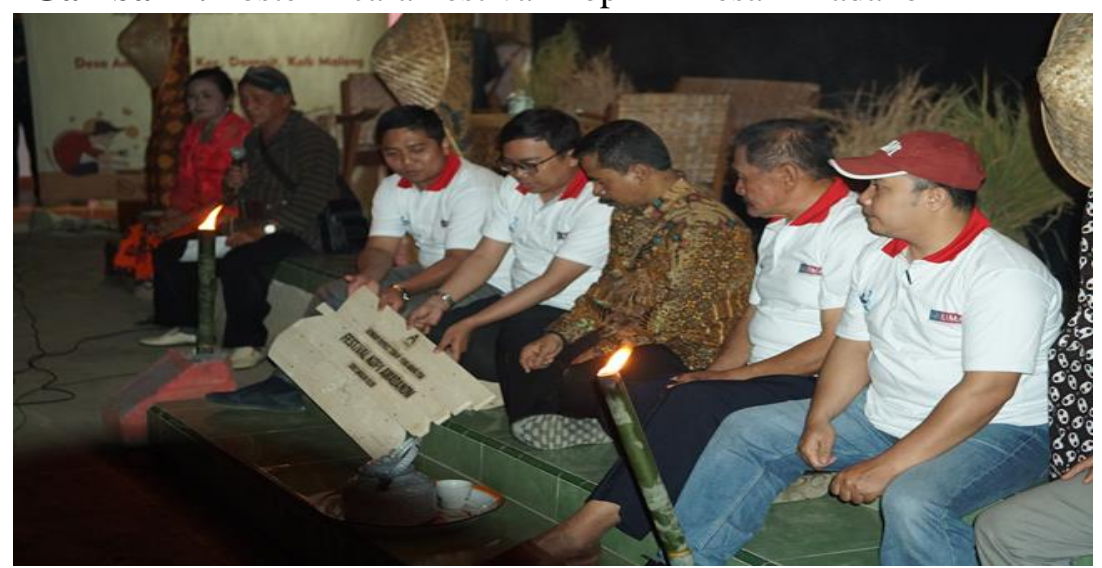

Gambar 8. Penandatanganan Prasasti Kopi di Desa Amadanom oleh Kepala Dinas Pemberdayaan Masyarakat dan Desa Kabupaten Malang, Drs. Suwadji., S.IP. M.Si. didampingi oleh tim pengabdian 


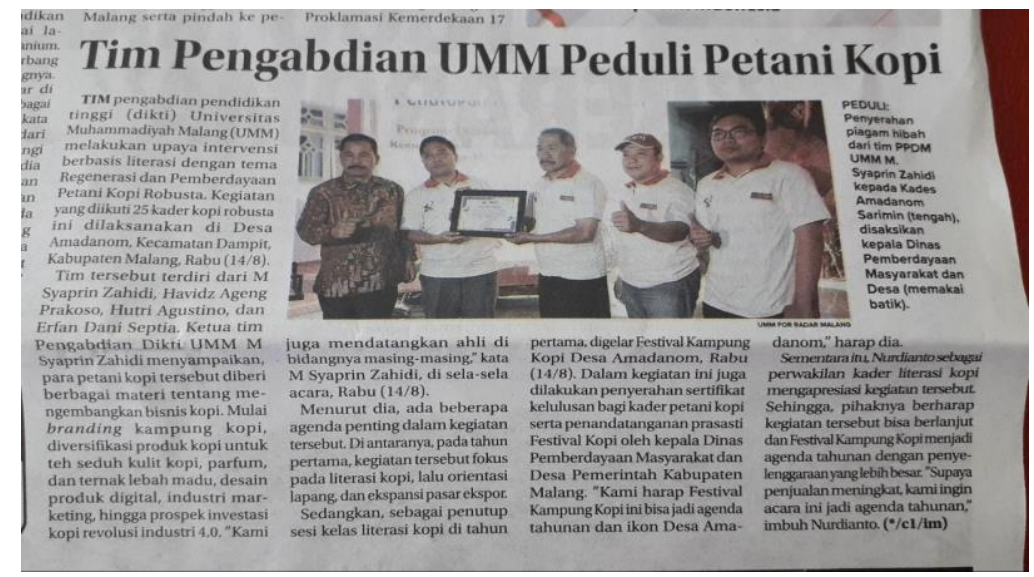

Gambar 9. Acara Festival Kopi dimuat oleh harin Radar Malang pada tanggal 16 Agustus 2019.

Kelas literasi kopi dan festival kopi ini pada akhirnya memiliki pengaruh besar pada animo masyarakat terutama generasi muda di Desa Amadanom untuk melanjutkan profesi orang tuanya. Hal ini menurut kami sangat bermanfaat karena produk kopi robusta dari Desa Amadanom akhirnya akan tetap terjaga karena sudah ada generasi-generasi muda yang berkomitmen untuk melestarikannya.

\section{SIMPULAN}

Berdasarkan pada hasil pengabdian kami maka dapat kami simpulkan bahwa kelas literasi kopi yang kami inisiasi melalui program pengabdian ternyata mampu memberikan narasi baru tentang kopi kepada generasi millenial di Desa Amadanom sehingga akan sangat bermanfaat bagi keberlanjutan hasil kopi robusta dari Desa Amadanom.

\section{SARAN}

Terima kasih kami tujukan kepada Kementerian Perindustrian dan Pendidikan Tinggi melalui Program Pengabdian Desa Mitra serta kepada Universitas Muhammadiyah
Malang yang telah mendukung kegiatan pengabdian kami secara kelembagaan.

\section{DAFTAR PUSTAKA}

BPS KABUPATEN MALANG. (2018). Kecamatan Dampit Dalam Angka 2018.

Katarika, D. M., \& Syahputra. (2017). Pengaruh Store Atmosphere Terhadap Keputusan Pembelian Pada Coffee Shop Di Bandung. Jurnal Ecodemica, Vol 1 No 2, 152-161. https://doi.org/10.1017/CBO978110741532 4.004

Mubarok, Ilham, \& Ghozi, Muhammad. (2019). "Coffee Shop di Kota Malang".Hasil Wawancara Pribadi: 19 Juli 2019, Kota Malang

Sarimin. (2019). "Generasi Muda Dan Petani Kopi". Hasil Wawancara Pribadi: 21 Juli 2019, Balai Kantor Desa Amadanom

Suliyadi. (2019)."Regenerasi Petani Kopi". Hasil Wawancara Pribadi: 22 Juli 2019, Kantor Kelompok Tani Harapan Amadanom 